\title{
Cryptosporidium spp., comparative diagnosis and geospatial distribution in diarrheic calves from dairy farms, Valdivia, Chile
}

\author{
Diagnóstico comparativo y distribución geoespacial de \\ Cryptosporidium spp., en terneros diarreicos en lecherías de \\ Valdivia, Chile
}

\author{
Pamela Muñoz A, ${ }^{1 *}$ M.Sc, Rubén Mercado $P_{1}^{2}$ Ph.D, Gabriela Morales $T^{1}{ }^{1} M V$, \\ Viviana Bravo O, ${ }^{1}$ MV, Eduardo Raffo C, ${ }^{1,3}$ MV.
}

\begin{abstract}
${ }^{1}$ Austral University of Chile, Faculty of Veterinary Science, Valdivia, Chile. ${ }^{2}$ University of Chile, Medicine School, Santiago, Chile. ${ }^{3}$ Austral University of Chile, National Commission for Scientific and Technology Research of Chile (CONICYT) Doctorate Program in Veterinary Science, Valdivia, Chile. *Correspondence: pamela.munoz@uach.cl
\end{abstract}

Received: April 2013; Accepted: September 2013.

\begin{abstract}
Objective. To determine the Cryptosporidium spp. infection frequency by using Ziehl-Neelsen and Auramine stains on samples obtained from diarrheic calves from milking farms of the Valdivia province. To compare both diagnostic tests and to determine the geospatial distribution of the infections caused by this protozoan. Materials and methods. 221 fecal samples of diarrheic calves of 24 milking farms of the Valdivia province were studied. The processing and analysis of the samples was done by Ziehl-Neelsen (ZN) and Auramine (AU) staining techniques, and the results were compared by McNemar statistical test and the concordance level was determined by kappa index. A map was also generated to determine the geospatial distribution of Cryptosporidium infections. Results. 57.9\% of all the animals tested were classified as positive with the ZN stain test, while $55.6 \%$ of all the animals turned out positive for the AU stain test. The McNemar test showed no significant difference between both diagnostic techniques ( $p>0.05$ ), while the kappa index showed proper concordance between tests $(\kappa=0.73) .100 \%$ of the farms studied showed protozoan presence demonstrating the broad distribution of the parasite, however, and considering the previous factor, it was not possible to determine geospatial associations for the parasite distribution. Conclusions. The infection frequency of Cryptosporidium is higher than $50 \%$ in the milking farms studied from the Valdivia province. No difference between the Ziehl-Neelsen and Auramine staining techniques was demonstrated showing very consistent results. It was possible to detect that the number of farms infected correspond to $100 \%$ of the farms analyzed.
\end{abstract}

Key words: Bovine, diarrhea, feces, infection, parasite, protozoa (Source: DeCS). 


\section{RESUMEN}

Objetivo. Determinar la frecuencia de infección por Cryptosporidium spp., mediante las tinciones de Ziehl-Neelsen y Auramina en terneros diarreicos de predios lecheros de la provincia de Valdivia. Comparar ambas pruebas diagnósticas y determinar la distribución geoespacial de las infecciones causadas por este protozoo. Materiales y métodos. Se estudiaron 221 muestras fecales de terneros diarreicos pertenecientes a 24 predios de la provincia de Valdivia. El procesamiento y análisis de las muestras se realizó mediante tinción de Ziehl-Neelsen (ZN) y Auramina (AU); y ambas técnicas se compararon mediante la prueba estadística de McNemar y su nivel de concordancia se determinó mediante índice kappa. Se generó además un mapa para determinar la distribución geoespacial de las infecciones por Cryptosporidium. Resultados. Del total de animales muestreados, 57.9\% resultaron positivos a ZN, mientras que $55.6 \%$ fueron positivo para AU. En la prueba de McNemar no hubo diferencia significativa entre los métodos diagnósticos estudiados ( $p>0.05)$, en tanto el índice kappa determinó una concordancia buena entre ambas pruebas $(\kappa=0.73)$. Del total de predios georeferenciados el $100 \%$ resultó positivo a la presencia del protozoo; demostrándose que ésta parasitosis tiene una amplia distribución; sin embargo, dado este factor, no fue posible determinar asociaciones geoespaciales sobre la distribución de éste. Conclusiones. La frecuencia de infección por Cryptosporidium supera el $50 \%$ en los predios lecheros de la provincia de Valdivia. No hubo diferencia entre las técnicas Ziehl-Neelsen y Auramina con resultados concordantes. Fue posible detectar que el número de predios infectados corresponde al $100 \%$ de los predios analizados.

Palabras clave: Bovino, diarrea, heces, infección, parásito, protozoa (Fuente: DeCS).

\section{INTRODUCCIÓN}

La criptosporidiosis es una enteroparasitosis de distribución cosmopolita, causada por el protozoo Cryptosporidium spp., cuyo principal signo clínico en el hospedero es la diarrea no hemorrágica $(1,2)$. La criptosporidiosis es considerada una enfermedad zoonótica por eso su importancia desde el punto de vista de la salud pública (3). En los bovinos afecta principalmente a los terneros recién nacidos que adquieren el parásito por vía oral $(1,4)$, siendo la principal fuente de infección las heces de los individuos jóvenes o neonatos con diarrea y aquellos animales adultos que actúan como portadores asintomáticos (2). Otra fuente importante de infección para terneros neonatos la constituyen los pezones de la vaca o los baldes de leche sustituta, que puedan estar contaminados con ooquistes del parásito (4).

Con respecto a la prevalencia de la enfermedad, los primeros reportes en Chile de hallazgo de Cryptosporidium en bovinos se producen en el año 1986, estudio en el que se determinó la presencia de este protozoo en 12 terneros de un total de 51 animales diarreicos. Luego en 1989, un estudio realizado en la región Metropolitana determinó niveles de prevalencia menores, el $2.2 \%$ en animales sanos $y$ el $23 \%$ en animales diarreicos $(5,6)$. Después en el año 1997, un estudio realizado en terneros diarreicos, reportó una prevalencia de $30.6 \%$ en el sur de Chile (6). El estudio más reciente en el país, corresponde al realizado por Díaz-Lee et al (5) en la región Metropolitana donde se analizaron 205 muestras de terneros diarreicos, pertenecientes a 2 predios lecheros, determinándose una frecuencia de infección de un $57 \%$.

\section{INTRODUCTION}

Cryptosporidiosis is a parasite infection with cosmopolitan distribution, caused by the Cryptosporidium spp. protozoan, the main clinical sign of which in the host is nonhemorrhagic diarrhea $(1,2)$. Cryptosporidiosis is considered to be a zoonotic disease, hence its importance from the public health point of view (3). In cattle, it mainly affects newborn calves that acquire the parasite orally (1.4), being the feces of newborns or young individuals with diarrhea and adult animals that act as asymptomatic carriers the main source of infection (2). Cow's teats or substitute milk buckets, which may be contaminated with the oocysts of the parasite, are another important source of infection for newborn calves (4).

With respect to the prevalence of the disease, the first reports in Chile of the discovery of Cryptosporidium in cattle, are produced in the year 1986, a study where the presence of this protozoan was determined in 12 calves from a total of 51 diarrheic animals. Then in 1989, a study conducted in the Metropolitan region found lower prevalence levels, $2.2 \%$ in healthy animals and $23 \%$ in diarrheic animals $(5,6)$. Then in 1997, a study conducted on diarrheic calves, reported a prevalence of $30.6 \%$ in the south of Chile (6). The latest study in the country is that conducted by Diaz-Lee et al (5) in the Metropolitan region, where 205 samples of diarrheic valves belonging to 2 dairy farms were analyzed, determining an infection rate of $57 \%$. 
Con respecto al diagnóstico de laboratorio de esta parasitosis, en animales de ganado existen diferentes métodos para la detección de ooquistes de Cryptosporidium, como la tinción de ZiehlNeelsen modificada o la tinción de Auramina (5). Ambas tinciones se aplican sobre extendidos de heces previamente concentrados y luego se observan en el microscopio óptico y de luz ultravioleta para fluorescencia, respectivamente (7). Se describe que la técnica de Auramina presenta ventajas ante la tinción de Ziehl-Neelsen al ser un método más rápido y eficaz de diagnóstico de ooquistes de Cryptosporidium spp., debido a que la inversión de tiempo durante la realización de la tinción y lectura de los frotis, resulta ser menor, por lo que es mayormente utilizada para análisis de un gran número de muestras o bien para estudios epidemiológicos o epizootiológicos (8).

Este estudio tuvo como objetivo determinar la frecuencia de infección por Cryptosporidium spp., en terneros diarreicos de predios lecheros mediante las tinciones de Ziehl-Neelsen y Aramina; comparando el rendimiento de ambas pruebas diagnósticas mediante la prueba estadística de McNemar y la concordancia de éstas mediante el índice kappa; y generar un mapa de distribución geoespacial de las infecciones provocadas por este protozoo en terneros de lechería pertenecientes a la provincia Valdivia.

\section{MATERIALES Y MÉTODOS}

Muestras. Se recolectaron muestras de heces de terneros diarreicos, con edades entre 1 y 35 días, entre los meses de mayo 2010 hasta abril del 2011. Éstas fueron obtenidas directamente del recto de cada animal y cada muestra fue depositada en tubos de $50 \mathrm{~mL}$ que contenían $25 \mathrm{~mL}$ de etanol al $70 \%$, con su respectiva identificación (número de cada animal, sexo, edad y predio). Las muestras fueron trasladadas al laboratorio de Parasitología de la Facultad de Ciencias Veterinarias de la Universidad Austral de Chile para su posterior análisis.

Procesamiento. De cada muestra se realizaron 2 extendidos de material fecal sobre portaobjetos, uno para tinción con Ziehl-Neelsen y otro para Auramina, los que se dejaron secar a temperatura ambiente para luego ser teñido según protocolo de Fredes et al (9) para Ziehl-Neelsen y según Fayer y Xiao (7) para Auramina.

Distribución geoespacial. Se registraron todas las coordenadas de latitud y longitud geográficas desde donde se obtuvieron muestras fecales de terneros mediante el uso de un GPS portátil de uso civil. Los datos fueron obtenidos y registrados con el sistema de grilla WGS-84 identificando
With regard to the laboratory diagnosis of this parasitism, in livestock animals there are different methods for detecting oocysts of Cryptosporidium, such as the modified ZiehlNeelsen stain or the Auramine stain (5). Both stains are applied on previously concentrated feces and then are observed in an optical and ultraviolet light microscope for fluorescence, respectively (7). The Auramine technique shows advantages to the Ziehl-Neelsen stain as it is faster and more efficient method for the diagnosis of oocysts of Cryptosporidium spp., since the time investment during the staining process and the reading of the smear proves to be less, so it is mostly used for the analysis of a large number of samples or for epidemiological or epizootiological studies (8).

The objective of this study was to determine the frequency of infection by Cryptosporidium spp. in diarrheic calves from dairy farms through Ziehl-Neelsen and Auramine stains; comparing the performance of both diagnostic tests using the McNemar statistical test and the consistency of these through the kappa index; and generate a geospatial distribution map of infections caused by this protozoan in dairy calves from the Valdivia province.

\section{MATERIALS AND METHODS}

Samples. Feces samples from diarrheic calves were collected, with ages raging between 1 and 35 days, between the months of May 2010 to April 2011. These were obtained directly from the rectum of each animal and each sample was placed in $50 \mathrm{~mL}$ tubes containing $25 \mathrm{~mL}$ of ethanol at $70 \%$, with their respective identification (number of each animal, gender, age and farm). The samples were transferred to the parasitology laboratory of the Faculty of Veterinary Science of the Austral University of Chile for further analysis.

Processing. From each sample two fecal smears were placed on a slide, one for ZiehlNeelsen stain and another for Auramine stain, which were left to dry at room temperature to then be stained according to the protocol of Fredes et al (9) for Ziehl-Neelsen and according to Fayer and Xiao (7) for Auramine.

Geospatial distribution. All the geographical latitude and longitude coordinates where fecal samples from calves were obtained were recorded through the use of a portable GPS for civilian use. Data were obtained and registered with the WGS-84 grid system identifying coordinates and the corresponding 
coordenadas y el huso geográfico correspondiente. La información obtenida fue transferida a un mapa en blanco en el software Arc-Gis generándose una capa (layer) con los puntos de obtención de las muestras. A este mapa en blanco se le agregaron capas de información como propiedad de la tierra, curvas de elevación, hidrología, tipos de suelo y vegetación, con el fin de determinar criterios de riesgo para la presencia del parásito (10).

Análisis estadístico. Los resultados se analizaron mediante la prueba estadística de McNemar para proporciones correlacionadas o dependientes. Mientras que para determinar los niveles de concordancia entre ambas pruebas, se utilizó el índice kappa (K) (11). Toda la información recopilada fue ingresada a una base de datos generada en el programa computacional Microsoft ${ }^{\circledR}$ Excel 2003.

\section{RESULTADOS}

Se muestrearon 24 predios lecheros pertenecientes a la provincia de Valdivia. De éstos se obtuvieron 221 muestras de heces de terneros diarreicos. Ciento veintiocho resultaron positivas a tinción de Ziehl-Neelsen, lo que corresponde al 57.9\% del total de muestras (Tabla 1 ). En todas las muestras positivas se hizo evidente la presencia de abundantes elementos esféricos de tamaño entre 4-6 $\mu \mathrm{m}$, con bordes delimitados y teñidos de color fucsia (Figura 1). Con respecto a la tinción de Auramina, 123 muestras resultaron positivas lo que corresponde al $55.6 \%$ del total de muestras (Tabla 1). En éstas se encontró la presencia de elementos esféricos de tamaño aproximado entre 4-6 $\mu \mathrm{m}$, irregularmente teñidos de color verde fluorescente (Figura 2).

Del total de terneros diarreicos estudiados, el $48.9 \%$ resultaron positivos a ambas pruebas diagnósticas y el $35.7 \%$ resultaron negativos tanto para Ziehl-Neelsen como para Auramina (Tabla 2).

Table 1. Frequency of infections of Cryptosporidium spp., using the Ziehl-Neelsen (ZN) and Auramine $(\mathrm{AU})$ techniques (absolute value and \%) in feces samples from diarrheic calves belonging to 24 dairy farms in the Valdivia province $(n=221)$.

\begin{tabular}{ccc}
\hline Diagnostic Test & Positive n & Positive \% \\
\hline ZN & 128 & $57.9 \%$ \\
AU & 123 & $55.6 \%$ \\
\hline
\end{tabular}

geographical zone. The information obtained was transferred to a blank map on the Arc-Gis software generating a layer with the sampling points. Layers of information were added to this blank map such as land ownership, elevation curves, hydrology, soil and vegetation types, in order to determine risk criteria for the presence of the parasite (10).

Statistical analysis. The results were analyzed using the McNemar statistical test for correlated or dependent proportions. While the kappa ( $\mathrm{k}$ ) index was used for determining the level of concordance between the two tests (11). All the information collected was entered into a database generated in the computer program Microsoft ${ }^{\circledR}$ Excel 2003.

\section{RESULTS}

Twenty-four dairy farms from the Valdivia province were sampled. From these 221 feces samples from diarrheic calves were obtained. One hundred twenty-eight turned out positive to the Ziehl-Neelsen stain, which corresponds to $57.9 \%$ of the total samples (Table 1 ). The presence of abundant spherical elements with a size between 4-6 $\mu \mathrm{m}$ was seen in all positive samples, with borders delimited and stained in fuchsia (Figure 1 ). With respect to the Auramine stain, 123 samples were positive which corresponds to $55.6 \%$ of the total samples (Table 1 ). The presence of spherical elements with an approximate size between 4-6 $\mu \mathrm{m}$ was found, unevenly stained in fluorescent green (Figure 2).

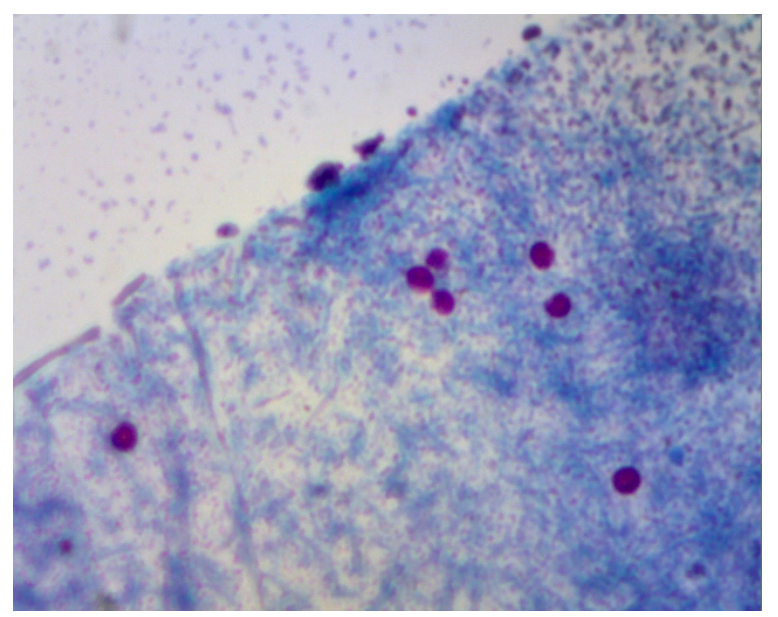

Figure 1. Microscopic observation of oocysts of Cryptosporidium in feces of diarrheic calves in the Valdivia province, stained using the Ziehl-Neelsen technique (100x). 


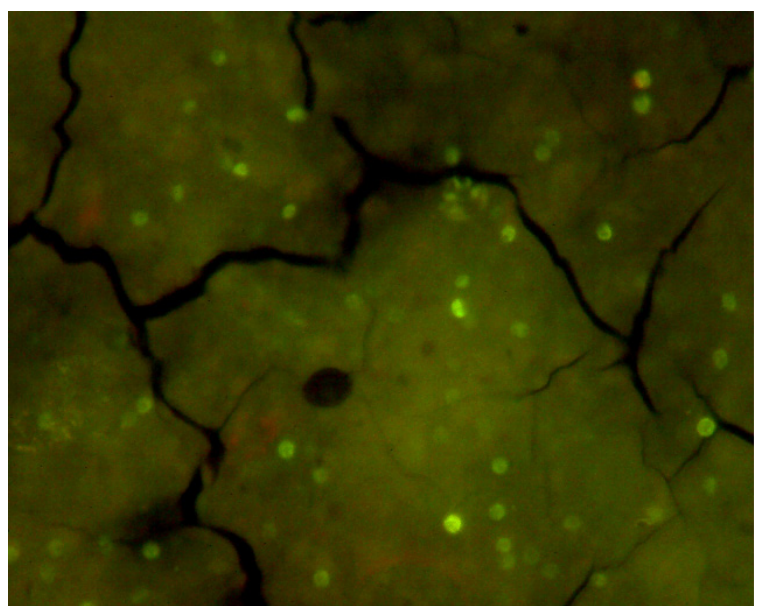

Figure 2. Microscopic observation of oocysts of Cryptosporidium spp. in feces of diarrheic calves in the Valdivia province, stained with Auramine technique (40x).

Mediante McNemar se determinó que no hubo diferencia significativa entre los dos pruebas de laboratorio empleadas ( $p>0.05$ ), en tanto el índice kappa mostró una buena concordancia entre las dos pruebas $(\kappa=0.73)$. Finalmente, del total de predios analizados $(n=24)$ el $100 \%$ resultó positivo a la presencia del protozoo.

El mapa con capas generado para la determinación de factores de riesgo geoespaciales no permitió realizar una discriminación ya que el $100 \%$ de los predios registrados presentó resultados positivos para la presencia del parásito estudiado, por lo que la distribución geoespacial no pudo asociarse a las características específicas del sector geográfico (Figura 3).
Table 2. Concordance of the results for feces samples of diarrheic calves analyzed using the microscopic techniques of Ziehl-Neelsen $(\mathrm{ZN})$ and Auramine (AU) (absolute value and \%).

\begin{tabular}{ccc}
\hline Results of Diagnostic Tests & $\begin{array}{c}\text { No. of Samples } \\
\text { Obtained }\end{array}$ & $\begin{array}{c}\text { Positive } \\
\text { Percentage \% }\end{array}$ \\
\hline Positive to Both (ZN and AU) & 108 & $48.9 \%$ \\
Positive to ZN & 128 & $57.9 \%$ \\
Positive to AU & 123 & $55.6 \%$ \\
Negative to Both (ZN and AU) & 79 & $35.7 \%$ \\
\hline
\end{tabular}

From the total of diarrheic calves studied, $48.9 \%$ turned out positive to both diagnostic tests and $35.7 \%$ were negative for both ZiehlNeelsen and Auramine (Table 2).

Using McNemar it was determined that there was no significant difference between the two laboratory tests employed $(p>0.05)$, insofar as the kappa index showed proper consistency between the two tests $(\kappa=0.73)$. Finally, from the total of farms analyzed $(n=24) 100 \%$ was positive to the presence of the protozoan.

The layered map generated for the determination of geospatial risk factors did not allow conducting a differentiation since $100 \%$ of the farms recorded showed positive results for the presence of the parasite under study, so the geospatial distribution could not be associated with the specific characteristics of the geographical area (Figure 3).

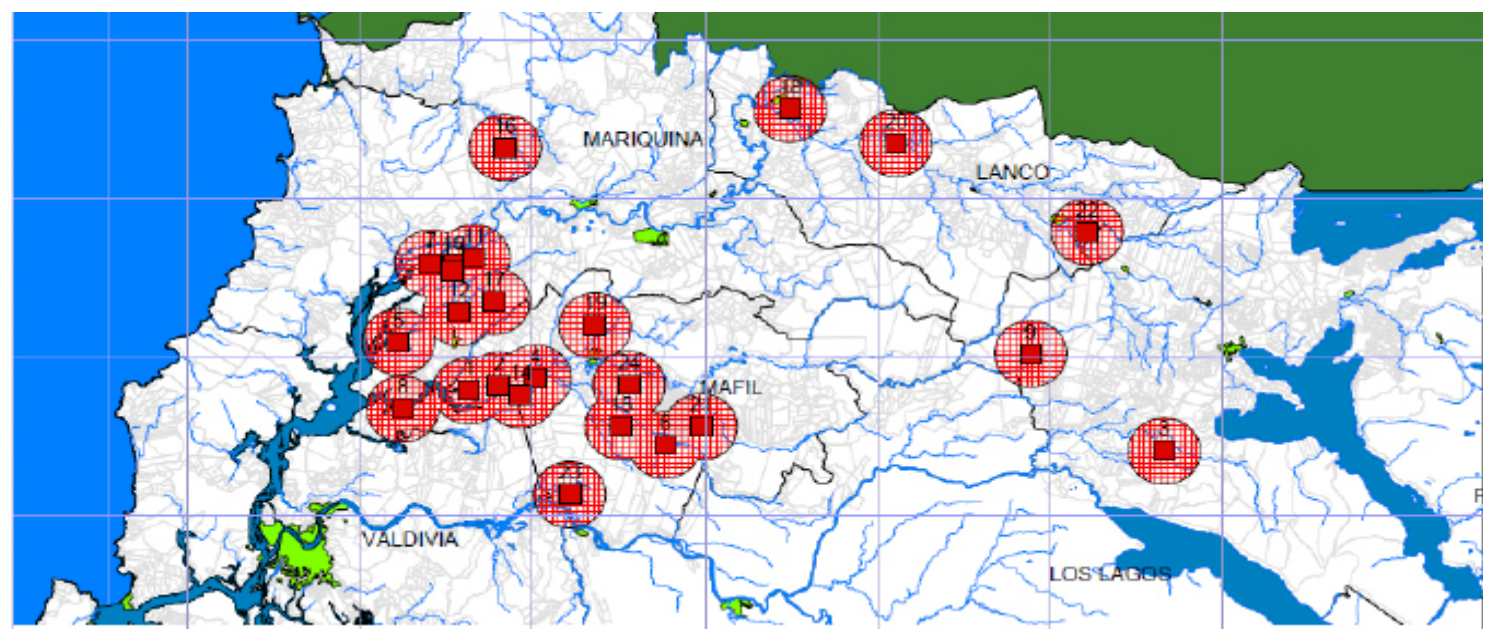

Figure 3. Geographical location and distribution of the 24 dairy farms positive to the Cryptosporidium spp. agent in the province of Valdivia, Chile. 


\section{DISCUSIÓN}

El alto nivel de infección por Cryptosporidium spp., observado en terneros de lechería de la provincia de Valdivia fue mayor con relación a los primeros registros observados en esta zona del país $(5,6)$; donde se reportó una prevalencia de criptosporidosis de $30.6 \%$ en las regiones del Maule, la Araucanía y Los Lagos. En este estudio se determinó aproximadamente el doble de las tasas de infecciones para la misma especie animal y el mismo rango etario. Por otra parte, en recientes estudios realizados en la Región Metropolitana se determinó un nivel de infección de $49.8 \%$ utilizando la técnica de Ziehl-Neelsen y $56.1 \%$ mediante Auramina, de un total de 205 terneros diarreicos pertenecientes a dos predios lecheros (5). Es importante destacar el hecho de que en el presente estudio, así como en el realizado por Díaz-Lee et al (5), se obtuvieron resultados que superan al $50 \%$ de animales positivos a este agente protozoario. Esto demuestra que la criptosporidiosis es una parasitosis que se mantiene prevalente y probablemente reemergente en el país.

Con respecto la prueba de McNemar demostró que no existen diferencias significativas entre las dos técnicas diagnósticas ( $p>0.05)$. De Quadros et al (8), en 331 muestras de heces en animales domésticos en donde comparó ambas técnicas, determinó que un 7.5\% de las muestras analizadas resultaron positivas a ZN y un $5.7 \%$ para $A U$ y $Z N$ demostrando que no hay diferencias significativas entre ambos métodos. Los autores exponen además, que la tinción de AU posee una mayor afinidad por la pared de los ooquistes de Cryptosporidium spp., que la fucsina utilizada en la tinción de $Z \mathrm{~N}$, demostrando que la primera tinción presenta ventajas ante la segunda al ser un método más eficaz de diagnóstico, ya que es de más rápida realización y lectura, por lo que es mayormente utilizado en un gran número de muestras o bien para estudios epidemiológicos. En cambio, en el estudio realizado por Díaz-Lee et al (5) se demuestra que existe diferencia entre ambos métodos, y que la tinción de $\mathrm{AU}$ presenta mayor sensibilidad que la de $Z N$, detectándose diferencia significativa $(p<0.05)$. Se ha sugerido que el método de ZN teñiría una pequeña proporción de los ooquistes presentes en una muestra y podría teñir un menor número de ooquistes que la prueba de AU (11); sin embargo, este mismo autor, estimó una sensibilidad aceptable para ambas técnicas diagnósticas. Con respecto al índice kappa se obtuvo como resultado que los niveles de concordancia entre ambas pruebas diagnósticas, es bueno $(\kappa=0.73)$, lo que condice con el nivel de concordancia logrado por Brook et al (12), donde el valor de $\kappa$ fue igual a 0.79 .

Respecto a las ventajas y desventajas que presentan las técnicas utilizadas, se debe mencionar que la principal ventaja de ZN como metodología diagnóstica, es su bajo costo, a esto se suma el hecho de que los

\section{DISCUSSION}

The high infection level by Cryptosporidium spp., observed in dairy calves of the Valdivia province was higher when compared to the first records observed in this part of the country $(5,6)$; where a $30.6 \%$ criptosporidosis prevalence was reported in the regions of Maule, Araucania and Los Lagos. In this study approximately twice the infection rates for the same animal species and the same age range were determined. On the other hand, in recent studies conducted in the Metropolitan Region an infection level of $49.8 \%$ was determined using the Ziehl-Neelsen technique and $56.1 \%$ using Auramine, from a total of 205 diarrheic calves belonging to two dairy farms (5). It is important to highlight the fact that in this study as well as in that conducted by Diaz-Lee et al (5), results exceeding $50 \%$ of animals positive to this protozoan agent were obtained. This proves that cryptosporidiosis is a parasitic infection that remains prevalent and will probably remerge in the country.

Regarding the McNemar test, it demonstrated that there are no significant differences between the two diagnostic techniques $(p>0.05)$. De Quadros et al (8), in 331 feces samples from domestic animals where both techniques were compared, determined that $7.5 \%$ of the samples analyzed turned out positive for ZN and 5.7\% for $A U$ and $Z N$, showing that there are no significant differences between both methods. The authors also stated that the AU staining has a greater affinity for the wall of the oocysts of Cryptosporidium spp. Than the fuchsine used for the ZN stain, demonstrating that the first stain has advantages to the second as it is a more effective diagnosis method, of faster execution and reading, so it is mostly used in a large number of samples or for epidemiological studies. In contrast, the study conducted by Diaz-Lee et al (5) demonstrates that there is a difference between both methods, and the AU staining has a greater sensitivity than ZN, detecting a significant difference $(p<0.05)$. It has been suggested that $\mathrm{ZN}$ method would stain a small proportion of the oocysts present in a sample and could stain a smaller number of oocysts than the AU test (11); however, this same author considered an acceptable sensitivity for both diagnostic techniques. With respect to the kappa index, it was obtained as a result that the level of concordance between the two diagnostic tests is good $(K=0.73)$, which is consistent with the level of concordance achieved by Brook et al (12), where the $\mathrm{k}$ value was equal to 0.79 .

Regarding the advantages and disadvantages of the techniques used, it is worth mentioning 
extendidos una vez teñidos, pueden ser conservados de forma permanente, a diferencia de la tinción de AU (12). Mientras que la desventaja que presenta ZN corresponde al mayor tiempo que se debe dedicar para la microscopia convencional $(11,12)$. Con respecto a la tinción de $\mathrm{AU}$ cabe destacar su rápida realización y lectura, pero los extendidos teñidos no se conservan de forma permanente y se requiere de un microscopio de campo oscuro dotado de luz ultra violeta para la observación de muestras teñidas, que no siempre está disponible en laboratorios clínicos; y finalmente la fluorescencia del fondo de la muestra podría representar un problema en la lectura de los extendidos cuando existe una gran cantidad de detritus fecales presentes en éstas (7).

Por otra parte, es importante considerar que se detectó ooquistes del agente protozoario en un ternero diarreico de 1 día de edad con posterior muerte del animal. El presente hallazgo se relaciona con lo registrado en el estudio de Díaz-Lee et al (5) quien también destaca el hecho de haber investigado 2 animales positivos a este protozoario al día de nacidos, es decir antes que trascurra el período prepatente (3 a 4 días) para esta infección en los bovinos (2). Una posible causa de encontrar ooquistes en terneros de 1 día, hace referencia a lo expuesto por Romero et al (4) implicando a los pezones de la madre, como una fuente importante de infección al estar contaminados con ooquistes de Cryptosporidium spp., los que ingresarían al sistema digestivo del ternero, en el momento en que éste mama el calostro. La eliminación de ooquistes en un período de tiempo menor al descrito en el ciclo de vida de este protozoo podría explicarse con el rol de hospedero de tránsito, que cumpliría el ternero de un día de edad eliminándose directamente a través de las heces. A la vez, cabe la posibilidad de que existan otras vías de transmisión por lo que es necesario hacer futuras investigaciones al respecto.

Con relación a la distribución geoespacial de las infecciones causadas por este protozoo se determinó que en los 24 predios muestreados se investigó la presencia de ooquistes de Cryptosporidium spp., lo que demuestra un alto nivel de infección en la provincia de Valdivia. No fue posible determinar los criterios de riesgo asociados a la presencia o ausencia del protozoo; ya que no hubo grupos, predios o sectores de la provincia negativos al agente. De la misma forma, las características de vegetación, calidad edafológica y cercanía a cursos hídricos fueron prácticamente compartidas por todos los predios, ya que todos corresponden a lecherías de características similares. En el presente estudio fue posible observar que todos los predios estudiados se encuentran cerca de cursos de aguas superficiales (Figura 1) constituyendo una posible fuente de infección para los bovinos. Se recomienda para futuros estudios, considerar el análisis e investigación de las aguas superficiales cercanas a estos predios positivos a that the main advantage of $\mathrm{ZN}$ as a diagnostic methodology is its low cost, coupled to the fact that once the smears have been stained, there may be stored permanently, as opposed to the AU stain (12). While the disadvantage of $\mathrm{ZN}$ is the longer time that must be used in conventional microscopy $(11,12)$. The quick execution and reading of the $A U$ stain is noteworthy, but the stained smears cannot be kept permanently and a dark field microscopy equipped with ultra violet light is required for the observation of stained samples, which is not always available in clinical laboratories; and finally the fluorescence on the bottom of sample could represent a problem in the reading of smears when there is a large amount of fecal detritus present in the same (7).

On the other hand, it is important to consider that oocysts of the protozoan agent were detected in a diarrheic calf of 1 day of age followed by the death of the animal. This find is related to that recorded in the study of Diaz-Lee et al (5) who also emphasizes the fact of having investigated 2 animals positive for this protozoan on the day of their birth, i.e. before the incubation period ( 3 to 4 days) for this infection in cattle (2). A possible cause of finding oocysts in calves of 1 day of age has been referred to by Romero et al (4) involving the teats of the mother as a major source of infection by being contaminated with oocyst of Cryptosporidium spp., which would enter the digestive system of the calf when drinking the colostrum. The elimination of oocysts in a smaller period of time than that described in the lifecycle of this protozoan may be explained by the role of the transit host, which would be fulfilled by the calf of one day old being eliminated directly through feces. In turn, it is possible that there are other routes for transmission so it is necessary to do further research on the subject.

In relation to the geospatial distribution of infections caused by this protozoan, it was determined that the presence of oocysts of Cryptosporidium spp. was investigated in the 24 farms sampled, which demonstrates a high infection level in the Valdivia province. It was not possible to determine the risk criteria associated with the presence or absence of protozoa; since there were no groups, farms or sectors in the province negative to the agent. Similarly, the characteristics of the vegetation, soil quality and proximity to watercourses were practically shared by all farms, since all correspond to dairies with similar characteristics. In this study it was possible to observe that all farms studied are near surface watercourses (Figure 1) constituting a potential source of infection for cattle. For future studies it is recommended to consider the analysis and research of surface watercourses near these 
infección por Cryptosporidium spp., con el fin de automatizar medidas necesarias para prevenir la diseminación de esta enfermedad entre los animales y su posible transmisión al ser humano con el consecuente perjuicio sanitario y económico.

En conclusión, se determinó que la frecuencia de infección por Cryptosporidium spp., en terneros de predios lecheros supera al $50 \%$ en provincia de Valdivia utilizando tanto la tinción de ZN como AU cuyos rendimientos y concordancia entre ambas pruebas fue buena. Finalmente fue posible detectar que el número de predios con criptosporidiosis correspondió al $100 \%$ de los predios analizados, observándose en el mapa una distribución uniforme asociada a los ambientes que son capaces de sostener una lechería de alta producción.

\section{Agradecimientos}

Este estudio fue realizado gracias a la financiación del proyecto DID UACH No S-2010-19 y FONDECYT 1121035. farms positive to infection by Cryptosporidium spp., in order to automate the necessary steps to prevent the spread of this disease among animals and its possible transmission to humans with the consequent health and economic damages.

In conclusion, it was determined that the frequency of infection by Cryptosporidium spp., in calves of dairy farms exceeds $50 \%$ in the Valdivia province using both the $\mathrm{ZN}$ stain and $\mathrm{AU}$ stain whose performance and concordance between the two tests was appropriate. Finally, it was possible to detect that the number of farms with cryptosporidiosis corresponded to $100 \%$ of the farms analyzed, observing a uniform distribution in the map associated with environments that are capable of sustaining a high production dairy.

\section{Acknowledgments}

This study was carried out thanks to the financing of the project DID UACH No S-2010-19 and FONDECYT 1121035.

\section{REFERENCES}

1. Taylor M, Coop R, Wall R. Veterinary Parasitology. Oxford, United Kingdom: Blackwell; 2007.

2. Thompson R, Olson M, Zhu G, Enomoto $S$, Abrahamsen M, Hijjawi N. Cryptosporidium and Cryptosporidiosis. Adv Parasitol 2005; 59:78-139.

3. Chalmers R, Campbell B, Crouch N, Davles A. Clinical laboratory practices for detection and reporting of Cryptosporidium in community cases of diarrhoea in the United Kingdom. Euro Surveill 2008; 15:1-5.

4. Romero R, Pedrozo R, Vera E. La cryptosporidiosis en los terneros recién nacidos. Su etiología, patogenia, síntomas, tratamiento y profilaxis. Revista de ciencia y tecnología 2001; 3:99-108.

5. Díaz-Lee A, Mercado R, Onuoha E, Ozaki $L$, Muñoz P, Muñoz V, Martínez F, Fredes F. Cryptosporidium parvum in diarrheic calves detected by microscopy and identified by immunochromatographic and molecular methods. Vet Parasitol 2010; 176:139-144.

6. Muñoz $P$, Fredes $F$, Díaz-Lee $A$, Mercado $R$, Ozaki L. Detección de Cryptosporidium spp. en terneras de lecherías de la Región Metropolitana mediante Ziehl Neelsen y confirmada por inmunocromatografía y ensayo molecular. Arch Med Vet 2011; 43:111-116.
7. Fayer R, Xiao L. Cryptosporidium and Cryptosporidiosis. New York, USA. Ed CRC Press, 2007.

8. De Quadros R, Marques $S$, Amendoeira $C$, De Souza L, Amendoeira P, Comparin C. Detection of Cryptosporidium oocysts by Auramine and Ziehl Neelsen staining methods. Parasitol Latinoam 2006; 61:117-120.

9. Fredes F, Raffo E, Muñoz P. First report of Cryptosporidium spp. oocysts in stool of Adélie penguin from the Antarctic using acid-fast stain. Antarct Sci 2007; 19(4):437-438.

10. Dohoo I, Martin W, Stryhn H. Veterinary Epidemiologic Research. Edward Island, Canadá. AVC Inc. 2003.

11. Hänscheid T, E Valadas. Diagnosis of Cryptosporidiosis using PCR or auramine $\mathrm{O}$ with LED fluorescent microscopy: Wich end of the stick? Acta Trop 2009; 109:247-248.

12. Brook E, Christley R, French N, Hart C. Detection of Cryptosporidium oocyst in fresh and frozen cattle faeces: comparision of three methods. Let Appl Microbiol 2008; 46:26-31. 